\title{
MEASUREMENT OF COMPANY INNOVATION POTENTIAL BY THE COMPLEX INNOVATION INDICATOR
}

\author{
Miroslav ŠPAČEK (DD* \\ Department of Corporate Economy, University of Economy and Management, \\ Nárožni 2600/9a, 15800, Prague, The Czech Republic \\ *E-mail: miroslav.spacek@vse.cz
}

\begin{abstract}
Purpose - this paper aims to fill the gap by the identification and assessment of factors of company innovation potential and integrates them into a complex innovation index. The index offers not only the metric to measure overall company potential to innovate but also uncovers areas which are problematic for smooth company innovation performance.
\end{abstract}

Research methodology - the Complex Innovation Index methodology consisted of qualitative research including a questionnaire survey in more than 50 companies and semi-conducted interviews with innovation managers and specialists.

Findings - the result is the software-based calculation of the Index which represents a simple but powerful tool which helps company managers better manage company innovation strategy and policy.

Research limitations - the methodology was aimed at the assessment of company innovation potential, no matter which industrial branch the company in question operates in. The methodology well suits to established companies but not to start-ups.

Practical implications - the methodology enables to reveal main deficiencies and weak points of company innovation processes. The interface is accessible to all companies that are inclined to have its innovation potential measured.

Originality/Value - the paper offers a unique and simple technique to measure the level of innovation capability in the company. It enables the company to identify deficiencies or weak points in its innovation performance.

Keywords: innovation measurement, Complex Innovation Indicator, innovation performance.

JEL Classification: O30, O31, O32.

Conference topic: Contemporary Organizations Development Management.

\section{Introduction}

The ability of a company to innovate is one of the most influential critical success factors (CSF) of sustainable company development. Innovation is considered a specific driving force that fosters company performance and reinforces company competitive position. Unfortunately, companies are not always aware of deficiencies in company innovation management that might create obstacles to effective innovation performance.

Furthermore, companies are sometimes too complacent to confess limited ability to innovate. Even if until present some attention has been paid to the effort to identify deficiencies and weaknesses of effective company innovation management, little attention was paid to its practical implications. This can be regarded as the gap in current knowledge of the subject. This paper aims to fill this gap and offers an approach to the determination of company innovation potential using a proven methodology to be based on empirical research. This methodology was elaborated in two modified forms to be applicable for both business and non-profit sector organisations. The point was to elaborate assessment method which takes into consideration, not only "hard" metrics that are easily measurable but also "soft" metrics, measurement of which requires more demanding and sophisticated approaches (questionnaire surveys, contextual interviews). The main result of the research is the construction of the Complex Innovation Index (from now on called "the Index") that enables measuring integral company innovation potential. It offers not only the metric to measure overall company potential to innovate but also uncovers areas which are problematic for smooth company innovation performance. This Complex Innovation Index was constructed from qualitative research including a questionnaire survey in more than 50 companies and semi-structured interviews conducted with innovation managers and specialists. 
The result is the software-based calculation of the Index which represents a simple but powerful tool that helps company managers better manage company innovation process. The gap identification as well as to the proposal to elaborate the Index allow to raise the following research question: "In what extent can the measuring innovation potential by the Index improve company's capability to innovate?".

\section{Current approaches to innovation measurement}

Many authors have addressed the problematics of innovation measurement over the past several decades (Evans \& Johnson, 2013; Moreno \& Garcia, 2014; Wang, Jin, Chang, \& Yao, 2014). It is necessary to admit that the surveys that were conducted were preferably aimed at the macro level (Foray \& Hollanders, 2015; European Innovation Scoreboard, 2018; Mamede, 2017). Mamede (2017) warns of using Innovation Union Scoreboard (IUS) to become the primary tool for innovation policy monitoring and benchmarking. Using comprehensive indicators like IUS for the assessment of innovation capabilities of European countries oversees a wide variety of economic structures among countries under analysis. He also proved a positive effect on country innovation policy if the country applied innovation measurement system. The reason for repeated addressing this topic was some dissatisfaction of company managers and innovation specialists with the existing status of innovation measurement. Some authors even consider innovation measurement critical success factor of innovation (Davila, Epstein, \& Shelton, 2012). Saunila (2017) confirmed that the companies which implemented the innovation management system and used innovation metrics achieved better financial and innovation performance. Milbergs and Vonortas (2004) put the development of metrics in the spotlight and introduced several metrics generation. The summary of their research is shown in Table 1.

Table 1. Four generations of innovation metrics (source: Milbergs \& Vorontas, (2004))

\begin{tabular}{|c|c|c|c|}
\hline $\begin{array}{c}\text { Input indicators of the 1st } \\
\text { generation (1950-1970) }\end{array}$ & $\begin{array}{c}\text { Output indicators of the 2nd } \\
\text { generation (1970-1990) }\end{array}$ & $\begin{array}{c}\text { Innovation indicators of the 3rd } \\
\text { generation (1990-2000) }\end{array}$ & $\begin{array}{c}\text { Innovation indicators of the 4th } \\
\text { generation (since 2000) }\end{array}$ \\
\hline & & & Knowledge \\
R \& D expenditures & Patents & Innovation researches & Networks \\
Scientific and technical staff & Publications & Indexing & Demands \\
Capital & Products & Benchmarking & Clusters \\
Technology intensity & Change in quality & Innovation capacities & Management techniques \\
& & & Risks/return \\
& & & System dynamics \\
\hline
\end{tabular}

The metrics of the first generation reflect linear innovation concept with the focus on inputs (e.g. investments in R\&D). The metrics of the second generation complement on input indicators by the inclusion of accounting indicators for scientific and technical cross-section outputs. The metrics of the third generation are oriented on innovation indicators and indexes which are based on surveys and publicly available data. The metrics of the fourth generation refer to the indicators of the knowledge economy which are measurable. According to the study of Boston Consulting Group (BCG) only $35 \%$ of respondents expressed their satisfaction with existing systems of innovation measurement (Emerald..., 2009). McKinsey in its global survey found out that even at companies that actively pursue innovation, $16 \%$ of executives confessed that their companies did not formally assess innovations at all (McKinsey..., 2008). The most common mistakes that the companies made during the setting of innovation measurement system consisted in using quantitative measures instead of qualitative ones (such as employees' skill level or the freedom employees have to explore fields outside the core business. Other companies overemphasised short-term measures over long-term measures because they viewed short-term measures as more convenient (Richtner, Brattstrom, Frishammar, Bjork \& Magnusson (2017). Companies, when dealing with innovation assessment very frequently resorted to financial metrics like Net Present Value (NPV), Economic Value Added (EVA) or Internal Rate of Return (IRR). The main disadvantage of this approach is the effect of company risk, which may have a significant impact on the assessment. Some authors recommend the adjustment of discount rate by a risk premium which takes into consideration company non-systematic risk (Brealey, Myers, \& Allen, 2010). In addition to these metrics, other approaches accentuate using different metrics like the relative ratio of investment expenditures into radical innovation concerning total investment expenditures. This approach can undermine innovation effort of companies that propel their growths by incremental innovations. Another indicator, construction of which resembles EVA, is a residual profit. The residual profit can be calculated as the net profit decreased by the multiplication of capital and capital costs. This indicator is based on the concept of economic profit which considers only that profit which exceeds total capital costs. This approach was successfully applied by Coca Cola, AT\&T, PepsiCo, Boeing etc. Project profitability is then estimated as the value generated during innovation life-time, and it is compared with expectations or similar projects (Bartoš \& Žižlavský, 2013). Malinoski \& Perry 
(2011) came up with the measures that include assessment of various parameters as (i) A ratio of number of ideas per 100 employees, (ii) percent of new ideas selected for funding, (iii) a ratio of revenue (or net profit) from new ideas divided by the average cost of implementation of an idea, (IV) aggregate ROI of new ideas implemented. They also came up with the indicator called Return on Product Development Expense (RoPDE)which can be easily calculated according to formula (1):

$$
R o D P E=\frac{(G M-P D E)}{P D E},
$$

where: $G M$ - Gross Margin; $P D E$ - Product Development Expense.

The advantage of this indicator is that it is derived from standard accounting data, can serve at multiple levels as a drill-down measure and can be integrated into any stage gate system or management process of the product life cycle (Malinoski \& Perry, 2011).

As opposed to financial metrics, marketing-based metrics became popular among company managers. Krawczyk (2013) pointed out that these metrics can be consolidated into two groups. The former includes customer satisfaction, customer loyalty, customer retention, the ability to attract new customers, acquisition, market share and customer profitability. The latter involves measures which determine the value of the product for the customer. This approach to innovation performance assessment was endorsed by the survey conducted by McKinsey Global Survey (2008). This study disclosed that the most frequently used metrics are Revenue growth due to new products and services (16\%) and customer satisfaction with new products and services $(13 \%)$.

Also, there are other hard metrics which precisely calculate specific parameters like the average duration of production program, the level of the product progressivity (Verlag Dasshofer, 2015) or parameters tied with the analysis of a product life cycle (Luz, de Francisco, \& Piekarski, 2015). All afore-mentioned metrics are applicable with advantage for product innovation. Beside product innovation, there is a demand to measure process innovation and organisational innovation as well. For these types of innovations, it is advisable to use different metrics. It is typical for process innovation to apply Return on process innovation which compares investments to process innovation against annual benefit from process innovation. Measurement of organisation innovation is a bit tricky because the effects of these innovations are manifested indirectly. The effects of organisation innovation can be recorded as the savings of personnel costs or the increase in labour productivity. Measurement of the effects of organisational innovation employing a questionnaire survey also enjoys a significant level of popularity. Some behaviourally-oriented metrics pay attention to the involvement of employees in the innovation process. By this way, it is possible to examine the average number of innovation proposals submitted by one employee.

Balanced Scorecard also gained a high level of popularity. This concept which was developed in early $90^{\text {th }}$ preferably as management tool supporting implementation and controlling of corporate strategy underwent slight modification to serve the purpose of innovation measurement (Davila et al., 2012; Bartoš \& Žižlavský, 2013; Krawczyk, 2013). Balanced Scorecard, thanks to its complexity, is a standalone methodology which can measure the effects of typologically different innovations. So-called Innovation Balanced Scorecard is composed of four components that are derived from and adapted to the innovative business model. These components (inputs - processes - outputs - results) enable to measure company innovation performance in its complexity and entirety. In general, the inputs are all resources entering the innovation process. Processes react to flexibility during the innovation project lifetime. The outputs measure all the effort which led to innovation and results represent the final effect which the company obtains from the innovation (Davila et al., 2012).

The companies which are listed on the Stock Exchange can use the correlation between relative investments into innovation (e.g. investment expenditure to sales) and share price increase (Špaček \& Vacík, 2016). Many metrics can be applied for innovation performance. Their choice depends on the type of innovation and feasibility of interpretation. Davila et al. (2012) not only insists on the interconnection of metrics with corporate strategy but also warns of the redundancy of metrics. Surveys conducted by BCG and McKinsey mentioned 5 and 8 metrics respectively to be routinely used by companies. This number of routinely used metrics is not sufficient, and BCG (2008) recommends using 9-12 metrics. Current trends pay respect to the measurement of innovation performance in every phase of the innovation process. By this way, the authors developed metrics which are focused on innovation performance measurement at the input of the project, during the project and at the end of the innovation project.

Typically, Fatur, \& Likar (2009) developed the methodology for idea management. For the same purpose, other authors propose measurement of funds invested into R \& D and education (Tura, Harmaakorpi, \& Pekkola, 2008; Eggink, 2012). Richtner et al., (2017) contradict enrooted practice to draw a great deal of attention to metrics. According to these authors, the main managerial challenge should not be pursuing metrics but to design and implement a useful and usable innovation measurement framework appropriate to the organisation's needs. They are convinced that placing too much value on the data at the expense of meaning might lead to contradictory advice. They offer a practical step-by-step framework that elucidate managers on possible suitability and applicability of current innovation measurement practices. If the current innovation measurement system fails to comply with company needs, they can propose the most effective solution. They created a solution that was able to avoid three main innovation measurement traps: (1) overestimating or underestimating the potential of innovation measurement, (2) measuring only the parts as opposed 
to the whole, and (3) overlooking the political power of innovation measures. To extricate from these traps, it is advisable to use a three-phase process that can help companies improve their innovation management practices: (A) assess current innovation measurement practices, (B) improve core innovation measurement practices, and (C) deploy the improved innovation measurement practices. Their methodology was verified on the pattern of more than 50 companies. Entire stepwise process commencing the assessment of current measurement practices through the improvement of current measurement practices to final deployment of measurement practices including seven sub-phases is shown in Figure 1.

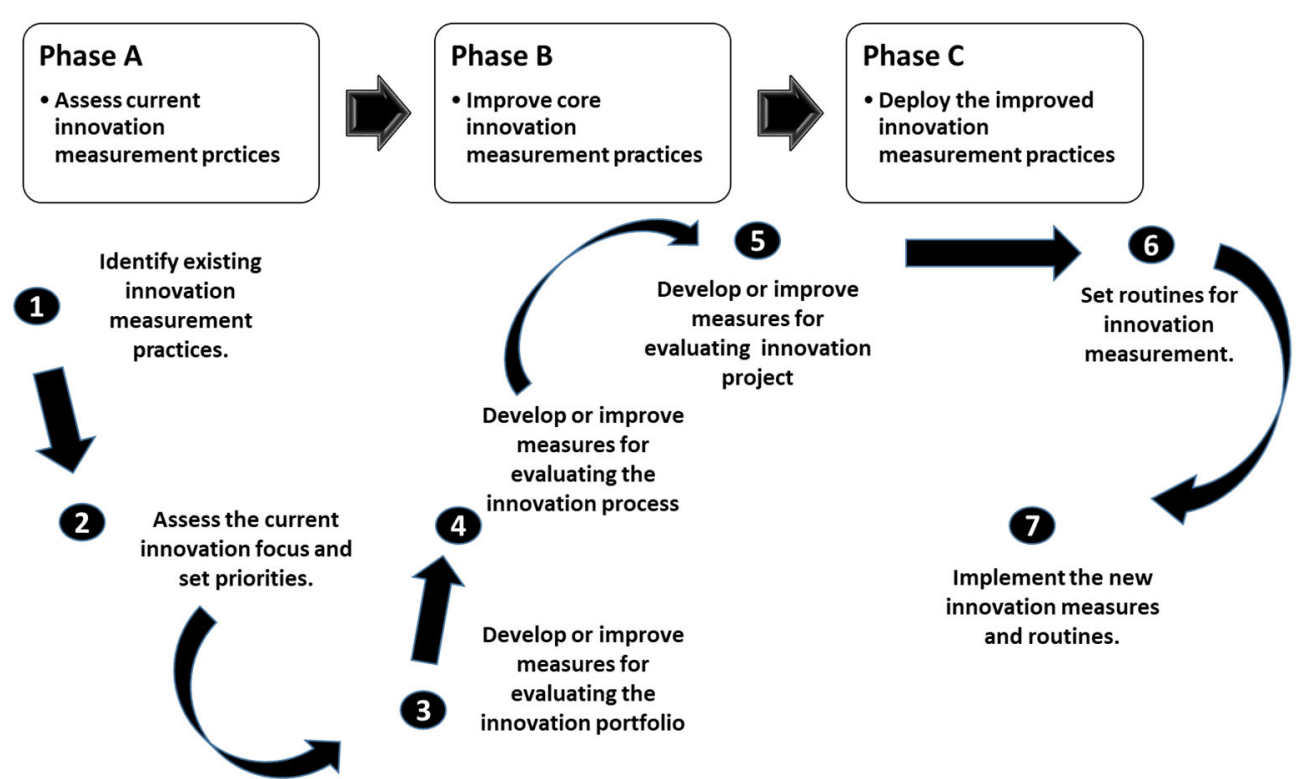

Figure 1. The process model of the replacement of current innovation measurement practices

by new ones (source: Richtner et al. (2017))

Apart from the measurement of the effects of innovations, the right measurement of innovation capability or innovation potential remains the challenge (Caffarel, Loera, Tienda \& Flores, 2012). Saunila and Ukko (2011) came up with the new concept of innovation capability which includes three elements:

- Innovation potential which consists of factors that affect the present state of innovation capability. It represents the potential that organisations have to produce innovation.

- Innovation processes that help an organisation utilise its innovation potential and thus enable innovation.

- The results of innovation activities are innovative products or processes.

Their model is introduced in Figure 2. The authors thus cast a different view on innovation capabilities and defined differences between innovation capability and innovation potential. According to authors the reason for the extension of the definition is the effort to see innovation capability more extensively as compared to innovation potential. The term innovation potential is perceived as the sub-category of innovation capability. The authors developed the system of innovation capability assessment via measurement of four perspectives (customers, processes, personnel and financial (Saunila \& Ukko, 2011).

There is continuous extensive research focused on the examination of innovation potential especially in terms of the identification of drivers which boost its efficiency. Nepelski \& Piroli (2018) explored the links of organisational diversity to innovation potential and found out that the innovation potential of homogeneous partnership (e.g. between two SMEs or two large companies) is higher as compared to that of heterogeneous partnership. Several authors made an effort to assess the innovation potential of industrial enterprises using integrated indicator. Kozlov, Teslya, and Zhang (2017) proposed the indicator which is composed of 23 parameters broken down into three groups. The indicator was purposefully developed to fit in with the coal-mining sector. The indicator was tested on the coal mine company in China. Innovation potential is also manifested on the macro level. Typically, boosting country innovation potential has a positive impact on the competitiveness of the national economy. Such dependence was proven in the cases of Germany and Austria (Lomachynska \& Podgorna, 2018).

\section{Research methods used}

The starting point for the methodology elaboration were principles and demands for the system of innovation measurement postulated in the scientific literature (Davila et al., 2012; Tidd, Bessant, \& Pavit, 2005). This theoretical basis 
was complimented on by the results of own research that examined and verified the opinions and practices of industrial companies in the innovation measurement system. At first, the researchers applied the content analysis to examine the quality and complexity of existing approaches to innovation measurement (Bryman \& Bell, 2015). This research helps reveal weaknesses and validity as well as the scope of applicability of current approaches to innovation measurement.

Furthermore, the methodology took advantage of qualitative research (Bryman \& Bell, 2015). The first part of the research was based on ethnographic research. According to Hume \& Mulcock (2004) "Ethnographic research involves the use of various techniques for collecting data on human beliefs, values and practices". Ethnographic research aimed to identify critical areas affecting innovation measurement to be incorporated in a complex indicator as well as to disclose specific parameters, measurement of which is essential for the reliability and validity on innovation indicator. Ethnographic research consisted of conducting semi-structured interviews. The responders were company managers, entrepreneurs, innovation specialists, idea champions and investors. The structure of interviews was focused on the effects that are conditional for effective innovation performance like (i) planning, defining and communication of strategy, (ii) innovation effort and innovation performance monitoring, (iii) learning and new opportunities identification. Each interview lasted approx. 1 hour and the key points (codes) of interviews were recorded manually.

A qualitative questionnaire survey accomplished the next part of the research. The original sample represented 96 Czech companies operating across industrial sectors. 55 responders provided the feedback. The underlying methodology assumption pointed out of necessity to include both hard (financial) and soft (behavioural) metrics so that the entire complexity of innovation benefits would be taken into consideration. The questionnaire consisted of 25 questions. The results of both ethnographic research and questionnaire survey enabled the research team to define four key areas to be critical for innovation performance. These groups stand for (1) conceptual activities of a company, (2) innovation resources and their management, (3) managerial infrastructure, (4) financial indicators of innovation performance. These findings build on innovation capabilities model developed by CEMEX-ITESM research group (Caffarel et al., 2012). Such a complex innovation measurement system reflected three essential roles which must be accomplished by measurement system (Davila et al., 2012): (i) planning, defining and communication of strategy, (ii) monitoring of innovation effort and evaluation of its performance and (iii) learning and new opportunities identification. CEMEX-ITESM model is depicted in Figure 2.

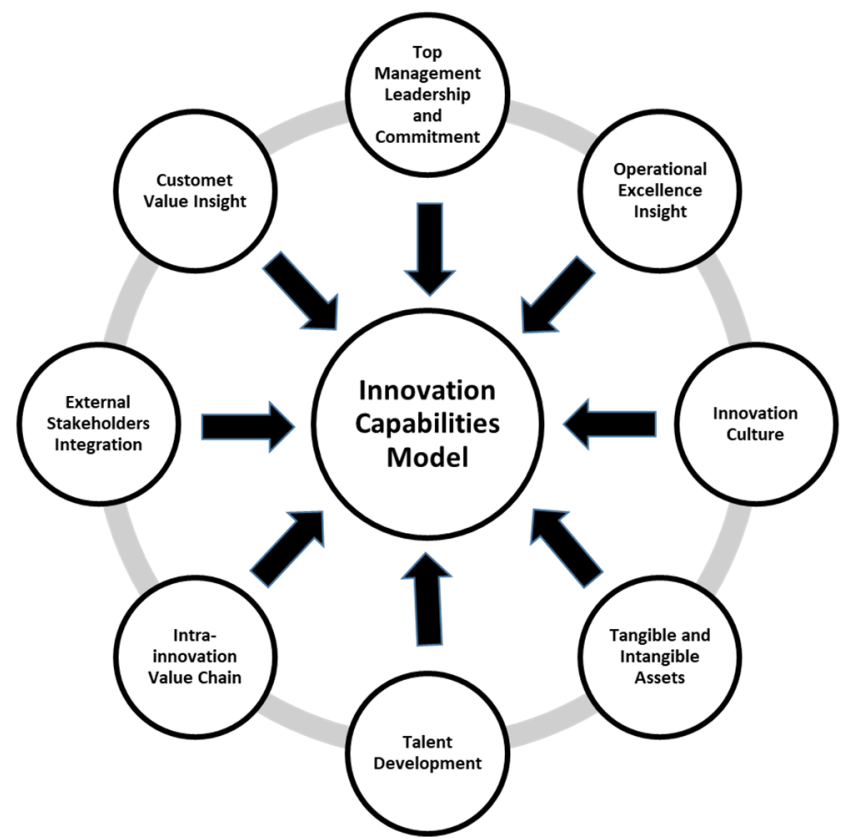

Figure 2. Organizational Innovation Capabilities Model (source: Caffarel et al. (2012))

CEMEX-ITESM model identified eight innovation capability drivers that have an impact on company capability to innovate. These findings became a point of departure for the execution of our research.

Finally, the research also leans on the qualitative case study. A qualitative case study is an intensive, holistic description and analysis of a bounded phenomenon such as a program, an institution, a person, a process, or a social unit. Qualitative methods concern meaning rather than frequency of phenomena. Emphasis is placed on case study design. It follows the primary logical sequence that connects the empirical data to the initial research questions and finally, to its conclusions (Yazan, 2015). Generally, the case study is a legitimate research strategy that resolves complex research problems. 


\section{Complex Innovation Index for Business sector}

The impetus to elaborate innovation index to be conducive to company innovation measurement came from the Ministry of Industry of the Czech Republic. The requirements for designing this management tool were quite demanding. At first, the Complex Innovation Index ("the Index") should be quite comprehensive which means it must cover innovation measurement of various types (product, process, organisational and marketing innovation). The individual measurable parameters should include both hard and soft metrics. The index must be transferable from one industrial branch to another with no fundamental changes. The technique of the Index calculation must not be too, and the calculation of the Index must proceed automatically through programmed software. Finally, the model must be appropriately validated not only by its practical testing but also by the endorsement of domestic and foreign expert opinions.

\subsection{Construction of the Index}

The Index is composed of 40 questions which are grouped into six thematic categories. The weights were assigned to each category on an expert basis by the method of allocation of 100 points. The relative relevance of each category is pointed out in Table 2 .

Table 2. The relative relevance of each category in the Index calculation (source: own research)

\begin{tabular}{|c|c|c|}
\hline The name of the section & Maximum point score in the category & Weight (\%) \\
\hline Conceptual activities of the company & 25 & 12.5 \\
\hline Resources management & 35 & 17.5 \\
\hline Managerial infrastructure & 45 & 22.5 \\
\hline Operational management of the innovation process & 65 & 32.5 \\
\hline Financial metrics & 20 & 10 \\
\hline Non-financial metrics & 10 & 5 \\
\hline Total score & 200 & 100 \\
\hline
\end{tabular}

It is apparent that the weights are distributed unevenly. It reflects mainstream management opinion that hard metrics, no matter if financial or non-financial, do not play a significant role in innovation potential assessment. The reason was that hard metrics namely financial indicators mapped rather past operational and financial performance than to be able to look forward. Innovation potential mapping is typical forward-looking activity.

These categories that were identified by ethnographic research include conceptual activities, managerial infrastructure, company resources management, innovation process management and financial and non-financial metrics). The objective was to structure innovation performance assessment according to individual sub-categories and thus refine the deficit in individual areas of innovation performance measurement. This approach enabled the company to point out of spheres of company innovation policy where the tested company operated in a sub-optimum way.

Underlying factor of the evaluation of company innovation potential and performance by the Index is the effective teamwork, deep involvement in innovation and innovation-oriented expert knowledge. The team formulates an adequate response to every question stepwise. Possible scale of responses, which can the assessor opts for, prevalently adhere to modified four-degree Likert scale. Depending on company ability to fulfil any parameter, the respective point score is assigned. (e.g. when the company fulfils the parameter at the maximum possible level then the company is awarded 5 points, if at a lower level then the point score stepwise decreases to 3-2-0). Maximum point score to be obtained from the response of one question is five. In the aggregate, responding all 40 questions at the maximum level of performance may lead to the maximum achievement of 200 points which theoretically represents ideal or top innovation performance. Partial point score is also obtainable for each of afore-mention innovation areas (categories). The Index was automatically calculated according to formula (1). The total point score is split as per individual categories of innovation performance so that the company might be aware of its weaknesses.

The example of the question, as well as the offer of potential answers with the assignation of optional point score, are listed below.

Question: Has the company a structured and formalised approach to assessing innovative ideas (e.g. checklist, scoring etc.)? Does this process also form an integral phase (ideation phase) of the corporate innovation process?

Answers:

1) The company formally introduced the system and consistently applied it. This phase is interlinked with the next phase of the corporate innovation process ( 5 points);

2) The company formally introduced the system and did not apply it consistently. A link to the subsequent phase of the innovation process is lacking ( 3 points);

3) The company formally introduced this system but did not apply it consistently ( 2 points);

4) The company does not have such a system processed (0 points). 


$$
\text { The Index }=\frac{\text { Sobtained points }}{200} \times 100[\%]
$$

\subsection{Instrumentation of the index}

In practice, the innovation potential assessment is handled through an interface which assures user-friendly comfort. All the calculations are performed automatically. The team of company experts and specialists to be in charge of the evaluation chooses the set of answers which at maximum extent correlate with actual innovation practice in the company. The engagement of the team to be cross-sectionally and interdisciplinary composed of employees of various professions is taken for granted.

\subsection{Interpretation of the Index}

It was already mentioned that the Index is calculated automatically immediately after completing the survey by the company persons. To make the assessment more user-friendly, the final point score is ranked among four categories. A specific level of innovativeness characterises each category. To each level of innovativeness, the authors assigned the explanatory notes. Classification of innovation performance based on the Index is shown in Table 3.

Table 3. Classification of companies based on their innovation performance (source: own research)

\begin{tabular}{|c|c|}
\hline Range of Complex Innovation Index [\%] & Position on the innovation scale \\
\hline $80-100$ & An excellently innovative company \\
\hline $60-79$ & A well innovative company \\
\hline $40-59$ & An average innovative company \\
\hline$<40$ & A below-average innovative company \\
\hline
\end{tabular}

All the innovation characteristics pointed out in Table 1 were qualitatively described in detail. The abbreviated illustrations of critical characteristics of each innovation class are presented below.

An excellently innovating company represents the company which innovation performance is excellent or almost excellent. It possesses all the attributes of an innovative organisation like structure, key individuals, high involvement in innovation, effective teamwork, systemic approach etc. Such a company is geared up for the transformation of ideas into an innovative solution. The company routinely uses both hard and soft innovation metrics that are conducive to the incorporation of feedback into the innovation process. The company has good access to capital to be used for innovation financing.

A well-innovating company follows in many aspects excellently innovating company but fails to meet some important criteria. The organisation achieves above-standard but not excellent innovation performance. The organisation implemented a formalised innovation process methodology which is with slight reservation respected.

An average innovating company perceives innovation as a recognised necessity which prevents the company from lagging behind competitors. Such a company develops radical innovation very rarely, and its growth is preferably based on incremental innovations. The company has restricted access to capital that prevents it from embarking upon ambitious innovation projects. The company is not attractive for young, ambitious employees

A below-average innovating company is an entity where the innovations do not play a decisive role. Such a company has not lost the capability to innovate, but its innovation potential is diminished. Company innovations, if any, are preferable of incremental character. The company does not systematically develop innovation-supporting corporate culture.

Initially, there was a category of non-innovative companies the total point score of which was below 10 points. Nevertheless, validation results and discussion with innovation experts advised excluding this category from the assessment. Calculation of company innovation potential using the Index is suitable especially for companies with trackable innovation history. It was designed for companies that have already implemented processes and set up the organisational structure. The methodology is not suitable for start-ups that neither established a formalised organisational structure nor adopted measurement system.

\subsection{Validation of the model}

The model was put on the software platform to enable the calculation to run automatically. The model was validated on the pattern of 15 companies that operated across different industrial branches (machinery, specialised chemistry, construction, pharmacy, oil industry, services etc.). The validation of the model was performed in collaboration with companies that were willing to comment on the relationship between the Index point score and actual company innovation performance. It was proven that the Index more tightly correlated with innovation performance of the companies 
that were preferably focused on industrial production than on service delivery. The possible reason is the easier measurability and quantifiability of the links between innovation and performance in production companies. Some problems were posed by the delay between the practical implementation of the innovation and its economic or other material effects. The contact to companies subjected to testing was mediated both through web portal Czech Top 100 (that consolidates the most influential Czech companies under one umbrella) and direct active contact with innovation managers from industrial sector (Czech Top 100, 2015). Model testing proceeded anonymously which was the essential pre-condition for companies subjected to testing. Basic value added to innovation assessment by the Index was the disclosure of areas with the deficit of innovation performance.

\section{Complex Innovation Index for the non-profit sector}

In addition to the elaboration of the Index for the business sector, there was a demand from the Ministry of Industry of the Czech Republic to elaborate similar methodology for non-profit organisations that would provide them with an appropriate tool for measurement of innovation in non-profit sectors. Since the concept of innovation and innovation management found a firm ground in the business sector, this was not the case in the non-profit sector. It dealt with institutions like theatres, galleries, exhibition halls, event organisation, music institutions etc. As opposed to managers in the business sector who were pretty familiar with the necessity to innovate and measure effects of innovation, the managers operating in the non-profit sector were quite puzzled with the demand to set up metrics to be applicable for the measurement of innovation in the non-profit sector. The research that was conducted in conjunction with this project applied preferably semi-structured or non-structured interviews with managers operated in a non-profit branch. Managers who took the interview were managers from the Czech Philharmonic Orchestra, Directors of both National and Technical Museums in Prague, private gallerists, open-air concert organisers, theatre managers etc.

The main obstacle to be resolved was the specification of what is and what is not innovation in the non-profit sector. As expected, the opinions differed from entity to entity and from manager to manager. Typical examples of innovation in non-profit sector were experience-based sightseeing tours, theatre performances in untypical environment, open-air opera performances, the presentations of established products in a new way (civic versions of historical opuses, interactive exhibitions, new ways of established products presentation, cross-genre opuses - e.g. combination of rock and philharmonic music, audiovisual performances, creative workshops or symposia organization etc.). Finally, the research team happened to fix the meanings and found common ground upon which the Index could be built up. The example of the question and possible answers are presented below:

Question: How does your organisation involve customers in the creation of innovative products?

Answers:

1) The organisation has in place a structured procedure for the involvement of customers into innovative product development that is systematically used in the innovation management process ( 5 points);

2) The organisation does not have in place a structured procedure for the involvement of customers; nevertheless, the organisation randomly engages the customer in innovation creation ( 3 points);

3) The organisation quite exceptionally engages a customer in innovative products creation ( 2 points);

4) The organisation does not engage customers in innovative products creation ( 0 points).

Based on the discussion with managers from the non-profit sector, the methodology was segmented among six areas:

1) Innovation marketing, financial and non-financial metrics of the organisation;

2) Conceptual activities of the organisation;

3) Innovation leadership and talent management;

4) Co-operation links of the organisation (innovation networking);

5) Innovation excellence and pro-innovation organisational culture;

6) Process and project innovation management.

According to expert opinions, this categorisation of innovation activities in non-profit sectors in the best possible way mirrors the complexity of innovation process management. These categories meet the demand for the segmentation (similarity within the segment and dissimilarity among the segments). Each category of innovation process measures the specific art of activities that are essential for effective innovation performance.

The methodology for the calculation of the Index for the non-profit sector was also put on the software platform. To facilitate the use of software support for the Index calculation, this calculation used technically the same software platform. It means 40 questions were raised; the responses being formulated on a modified Likert scale principle. Even if the number of questions was the same as that for the business sector, the content of questions differed significantly because of the different nature of the innovation process in the non-profit sector. It enabled the assessor to log in into the same interface (see in http://hodnoceni-inovaci.cz) then to opt for the methodology designed either for business or non-profit sector, step-by-step to pick up the responses which are the closest to actual company innovation status and by the final click to obtain the value of the Index. The model was validated on the patterns of the museum, philharmonic orchestra, regional cultural centre and public theatre house. The validation was completed by the interviews with respective managers of the cultural bodies. Preliminary results show that the reliability of the Index in the non-profit 
sector is lower than that in the business sector. This is due to the higher complexity and diversification of innovation activities across the non-profit sector.

\subsection{Case study - business sector}

PharmaComm Ltd company (PharmaComm) is the mid-sized Czech pharmaceutical company dedicated to the development and production of active pharmaceuticals ingredients (API). Since the beginning of the 80s the company has been continuously developing, producing and selling prostaglandins (hormonal products). These products are aimed at the treatment of men's erectile dysfunction, glaucoma, pulmonary arterial hypertension, oestrus cycle in cows and gynaecologic dysfunctions. The company survived sweeping political changes that took place at the beginning of the $90 \mathrm{~s}$, underwent several restructuring programs and finally was successfully privatised. Over the past decades, the company suffered from lower innovation performance as compared to competitors. Company management wanted to identify gaps and shortcomings in current innovation management and consequently find the way how to boost innovation performance. That was the reason for the managers to have innovation potential measured by the Index and based on the results to define future company innovation trajectory. Table 4 summarises the results of the Index evaluation for this particular company.

Table 4. The Index of PharmaComm Ltd company (source: own research)

\begin{tabular}{|c|c|c|c|}
\hline The name of the section & Actual point score & Maximum point score & Percentage \\
\hline Conceptual activities of the company & 21 & 25 & $84.00 \%$ \\
\hline Resources management & 27 & 35 & $77.14 \%$ \\
\hline Managerial infrastructure & 33 & 45 & $73.33 \%$ \\
\hline Operational management of the innovation process & 49 & 65 & $75.38 \%$ \\
\hline Financial metrics & 6 & 20 & $30.00 \%$ \\
\hline Non-financial metrics & 2 & 10 & $20.00 \%$ \\
\hline Total score & 138 & 200 & $69.00 \%$ \\
\hline
\end{tabular}

In general, the company belongs to the group of well-innovating company. It is apparent that the conceptual activities of the company are performed excellently. The findings are tied with the implementation of various management standards that are mandatory for the steady production of pharmaceuticals. It deals with ISO 9001, 14001, OHSAS 18001, GMP - Good Manufacturing Practice etc. Other highly relevant categories (resources management, managerial infrastructure and management of innovation processes are performed well but not excellently. There might be hidden potential for improvement. Remaining two categories that refer to hard metric showed that actual practices listed in these categories are not executed quite well. The company management has to draw attention to weak points and come up with some improvements. The index must be calculated again within a certain time distance to compensate for the delay between innovation execution and collecting benefits from the innovation.

\subsection{Case study: non-profit sector}

The methodology was tested on the example of the municipal theatre in the Central Bohemia. The Municipal Board supervises this theatre, and the contractual manager operates it. The manager was granted authority to operate the theatre on the principle of economic rent. He is held responsible for both repertoire selection and economic performance of the theatre. The theatre is partially subsidised by the Municipal Board that strives to minimise the subsidy. The theatre stages both in-house rehearsed plays where amateur actors were cast in lead characters and contracted theatre performances featuring famous professional actors from Prague. The manager who filled in the survey and responded the questions is open to new innovative ideas, but on the other hand, he is cautious of limited susceptibility of the regional audience to accept new and sometimes surprising formats of plays. Typically, he rehearsed and staged musical version of Jules Verne's Around the World in Eighty Days, where both music and lyrics were composed by regional authors and a combined team of amateur and professional actors were cats into lead roles. The Index calculation is shown in Table 5.

Despite the efforts made in favour of innovation, the result is rather sad. The manager is fully aware of the ambiguity of the situation where the theatre wants to offer innovative products, but the regional audience is inclined to accept instead proven and experiment-free performances. Notwithstanding discouraging results, the manager still wants to keep on innovation effort. He plans to take on board young and progressive people who would help him create a new face of the theatre. He plans to deepen networking with another progressive and innovative theatre groups and thus benefit from mutually shared experience. 
Table 5. The Index of the municipal theatre house in the Central Bohemia (source: own research)

\begin{tabular}{|c|c|c|c|}
\hline The name of the section & Actual point score & Maximum point score & Percentage \\
\hline Innovation marketing, financial and non-financial metrics of the organisation & 18 & 30 & $60.00 \%$ \\
\hline Conceptual activities of the organisation & 13 & 35 & $37.14 \%$ \\
\hline Innovation leadership and talent management & 13 & 35 & $37.14 \%$ \\
\hline Co-operation links of the organisation (innovation networking) & 14 & 35 & $40.00 \%$ \\
\hline Innovation excellence and pro-innovation organisational culture & 5 & 30 & $16.67 \%$ \\
\hline Process and project innovation management & 11 & 35 & $31.43 \%$ \\
\hline Total score & 74 & 200 & $37.00 \%$ \\
\hline
\end{tabular}

\section{Conclusions}

The methodology of the innovation assessment by the Index meets its objectives. It typically represents a useful management approach that applies to companies for innovation potential or innovation performance measurement. This methodology of innovation assessment builds on existing innovation capability models, increases their effectivity and interconnects them with actual managerial practice. It is a powerful tool that enables to reveal main deficiencies and weak points of company innovation processes. The interface posted on website http://hodnoceni-inovaci.cz/ is fully functional and accessible to all companies that are inclined to have their innovation potential measured. The most significant benefit of the methodology consists in the vast extent of applied indicators that enables to assess benefits of both radical and incremental innovations on one hand and product, process and organisational innovation on the other hand. Testing and validating the Index enabled to respond to the research question that was raised in the Introduction. The company ability to measure its innovation potential can provide the management team with a general overview of company innovation status.

Moreover, it discloses weak points in company innovation performance which drives the company to implement rectification measures. It also identifies innovation areas where the company operates in a sub-optimum way. As a consequence, the company can redefine its innovation processes to create an appropriately balanced innovation system. It is advisable to adopt a longitudinal approach and repeat the assessment within some reasonable time distance. This may compensate for the delay that is caused by the disparity between innovation implementation and reaping benefits out of it. The methodology based on the Index assessment is not a discriminating external assessment, but it is a tool of self-reflection. This methodology enables companies not only to assess the quality of ongoing innovation processes but also helps them find unused potential in their innovation business. The adjustment of the Index and its refining to the particular needs of individual business sectors is the topic for additional research.

The development of the Index for the non-profit sector posed a great challenge. Literature survey indicated that this problem had not been addressed yet. Based on interviews conducted with non-profit sector managers it became apparent that the only indicator to be used in the non-profit sector was the full attendance achieved during chosen timeperiod. Hardly can be this indicator considered the suitable measure for innovation. That is why the Indicator had to be developed from the scratch based on expert opinions of managers, experts and opinion leaders. As for the preliminary tests of the Index designed for the non-profit sector, it is apparent that the reliability of the Index is slightly lower than that for the business sector. This difference is due to a higher differentiation of innovation processes in the nonprofit sector. To improve the reliability of this specific Index, it is advisable to keep on data collection, ongoing testing the Index reliability to arrive at possible corrections and improvement of this methodology.

\section{Funding}

The Czech Technology Agency supported this research work under the Grant [TD020325].

\section{Disclosure statement}

The author does not have any competing financial, professional, or personal interests from other parties.

\section{References}

Bartoš, V., \& Žižlavský, O. (2013). Inovační scorecard jako prostředek měření inovační výkonnosti u MSP. Trendy Ekonomiky a management, 4(7). Retrieved from https://trendy.fbm.vutbr.cz/index.php/trends/article/view/139/125

BCG. (2008). Measuring Innovation. Squandered Opportunities. A BCG Senior Management Survey. Boston Consulting Group. Retrieved from https://www.bcg.com/documents/file15302.pdf

Brealey, R. A., Myers, S. C., \& Allen, F. (2010). Principles of Corporate Finance- Global Edition. McGraw-Hill Higher Education. 
Bryman, A. \& Bell, E. (2015). Business Research Methods. Fourth edition. Oxford University Press.

Caffarel, G., Loera, J. Tienda, E. E., \& Flores, M. (2012). Diagnosing tool for level of maturity of organizational innovation capabilities. In G. Lim and J. W. Herrmann (Eds.). Proceedings of the 2012 Industrial and Systems Engineering Research Conference.

Czech Top 100. (2015). Retrieved from https://www.czechtop100.cz/czech-top-100/o-sdruzeni/o-sdruzeni.html

Davila, T., Epstein, M. J., \& Shelton, R. D. (2012). Making Innovation Work: How to Manage It, Measure It, and Profit from It. Wharton School Publication.

Eggink, M. E. (2012). Innovation system performance: How to address the measurement of a system's performance. Journal of Innovation \& Best Practices. Retrieved from https://ibimapublishing.com/articles/JIBBP/2012/593268/593268.pdf. 2012, https://doi.org/10.5171/2012.593268

Emerald Group Publishing Limited. (2009). Innovation metrics: Some progress but could do much better. Strategic Direction, 25(4), 35-38. https://doi.org/10.1108/02580540910943550

European Innovation Scoreboard. (2018). European Commission. Retrieved from http://europa.eu/rapid/press-release_IP-184223_en.htm

Evans, J. D., \& Johnson, R. O. (2013). Tools for managing early-stage business model innovation. Research-Technology Management, 56(5), 52-56. https://doi.org/10.5437/08956308X5605007.

Fatur, P., \& Likar, B. (2009). The development of a performance measurement methodology for idea management. International Journal of Innovation and Learning, 6(4), 422-436. https://doi.org/10.1504/IJIL.2009.024137.

Foray, D., \& Hollanders, H. (2015). Scoreboard as a tool to analyse national innovation capacities: The case of Switzerland. Research Evaluation, 24(2), 213-228. https://doi.org/10.1093/reseval/rvu036.

Hume, L., \& Mulcock, J. (2004). Introduction: Awkward Spaces, Productive Places. In L. Hume \& J. Mulcock (Eds.), Anthropologists in the Field: Cases in Participant Observation (pp. 9-28). New York, NY: Columbia University Press.

Kozlov, A. V., Teslya, A. B., \& Zhang, X. (2017). Principles of assessment and management approaches to innovation potential of coal industry enterprises. Journal of Mining Institute, 223, 131-138.

Krawczyk, M. (2013). The use of marketing indicators to measure and monitor the effects of implementing the concept of userdriven innovation. Financial Internet Quarterly, e-Finance, 9(4), 53-60.

Lomachynska, I., \& Podgorna, I. (2018). Innovation potential: Impact on the national economy's competitiveness of the developed countries. Baltic Journal of Economic Studies, 4(1), 262-270. https://doi.org/10.30525/2256-0742/2018-4-1-262-270

Luz, L. M., de Francisco, A. C., \& Piekarski, C. M. (2015). Proposed model for assessing the contribution of the indicators obtained from the analysis of life-cycle inventory to the generation of industry innovation. Journal of Cleaner Production, 96(SI), 339348. https://doi.org/10.1016/j.jclepro.2014.03.004

Malinoski, M., \& Perry, G. S. (2011). How Do I Measure Innovation?!? Strategy Management Group, Balanced Scorecard Institute. Retrieved from https://www.balancedscorecard.org/portals/0/pdf/Howtomeasureinnovation.pdf

Mamede, R. P. (2017). Structural asymmetries, innovation measurement and innovation policies in the EU. Portuguese Journal of Social Science, 16(3), 377-392. https://doi.org/10.1386/pjss.16.3.377_1

McKinsey Global Survey. (2008). Assessing Innovation Metrics. McKinsey Quarterly, October 2008. Retrieved from http://innovbfa.viabloga.com/files/McKinseyQuaterly__assessing_innovation_metrics__oct_2088.pdf

Milbergs, E., \& Vonortas, N. (2004). Innovation Metrics: Measurement to Insight. Center for Accelerating Innovation and George Washington University. National Innovation Initiative 21st Century Working Group, September 22.

Moreno, R. S., \& Garcia, C. A. (2014). Innovation Capacity Assessment System in Small and medium Enterprises in Developing Countries: Case of Panama. Spain: Universidad Tecnológica de Panamá (ETP).

Nepelski, D., \& Piroli, G. (2018). Organizational diversity and innovation potential of EU-funded research projects. Journal of Technology Transfer, 43(3), 615-639. https://doi.org/10.1007/s10961-017-9624-6

Richtner, A., Brattstrom, A., Frishammar, J., Bjork, J., \& Magnusson, M. (2017). Creating Better Innovation Measurement Practices. MIT Sloan Management Review, 59(1), 45-53.

Saunila, M., \& Ukko, J. (2011). A conceptual framework for the measurement of innovation capability and its effects. Baltic Journal of Management, 7(4), 355-375. https://doi.org/10.1108/17465261211272139

Saunila, M. (2017). Managing continuous innovation through performance measurement, Competitiveness Review. International Business Journal, 27(2), 179-190. https://doi.org/10.1108/CR-03-2015-0014

Špaček, M., \& Vacík, E. (2016). Company value creation through effective innovation process management. Journal of Innovation Management, 4(3), 65-78. https://doi.org/10.24840/2183-0606_004.003_0006

Tidd, J., Bessant, J., \& Pavitt, K. (2005). Managing Innovation: Integrating Technological, Market and Organizational Change. John Wiley \& Sons.

Tura, T., Harmaakorpi, V., \& Pekkola, S. (2008). Breaking inside the black box: Towards a dynamic evaluation framework of regional innovative capability. Science and Public Policy, 35(10), 733-44. https://doi.org/10.3152/030234208X363169

Verlag, D. (2015). Kvalitativní a kvantitativní stránka inovačního procesu. Retrieved from https://www.qmprofi.cz/33/kvalitativnia-kvantitativni-stranka-inovacniho-procesu-uniqueidgOkE4NvrWuOKaQDKuox_Z41kjRqqI85k6DUTyINcuh4/

Wang, Y. Q, Jin, Q. Y, Chang, Z. G., \&Yao, L. X. (2014). The Assessment and Evaluation about the Ability of Technical Innovation for Petrol Equipment Manufacturing Enterprises Based on Fuzzy Comprehensive Evaluation Method. In Proceedings 3rd Conference on Energy, Environment and Sustainable Development (EESD 2013).

Yazan, B. (2015). Three approaches to case study methods in education: Yin, Merriam, and Stake. The Qualitative Report, 20(2), 134-152. Retrieved from https://nsuworks.nova.edu/tqr/vol20/iss2/12 